\title{
TESTVÉRGONDOZÁS - FELNŐTT ÉRTELMI FOGYATÉKOSOKAT GONDOZÓ TESTVÉREK
}

\section{Szerző:}

Pető Ildikó (PhD)

\section{Lektorok:}

Németh Nóra (PhD)

Gál Ferenc Egyetem (Magyarország)

Balázs-Földi Emese (PhD)

Debreceni Egyetem (Magyarország)

A szerző email címe:

peto.ildiko@ped.unideb.hu ...és további két anonim lektor

Pető Ildikó (2021). Testvérgondozás - felnőtt értelmi fogyatékosokat gondozó testvérek. Különleges Bánásmód, 7. (2). 111-121. DOI 10.18458/KB.2021.2.111

\begin{abstract}
Absztrakt
$\mathrm{Az}$ értelmi fogyatékos felnőttek egyre hosszabb élettartama új kérdéseket és feladatokat vetett fel a családok számára. Az értelmi fogyatékosok állapotuk súlyosságától függően különböző mértékben egész életükben a családjuk, a környezetük támogatására szorulnak. Függenek a családtagjaiktól, amely függés új problémát jelent, amikor a szülők idősödnek, a gondoskodás pedig a testvérek feladata lesz, akik már önálló életet élnek, időnként földrajzilag távol. A testvérgondozást egyértelmúen másképpen kell értelmezni, mint azt, amikor a szülő vagy egy fizetett szakember végzi, érzelmileg komplexebb, tartalma és iránya többféle. A testvérgondozókról keveset tudunk, egy-egy kérdéssel kapcsolatban csak feltételezett válaszaink vannak a kevés számú vizsgálat vagy a hasonló területeken végzett kutatások alapján. Jelen írás áttekintést kíván adni az értelmi fogyatékos testvérüket gondozó, értük felelősséget vállaló felnőttek helyzetéről, motivációiról, a megértésüket segítő többféle hatás szerepérôl és kölcsönhatásáról. A testvérgondozók megismerése szükséges, hogy a gyógypedagógia és a szociálpolitika támogató rendszere megfelelően alkalmazkodjon a sajnálatosan alig 'látható' populáció helyzetéhez.
\end{abstract}

Kulcsszavak: gondozás, értelmi fogyatékosság, testvérgondozók, testvérgondozás Diszciplína: pedagógia

\section{Abstract}

\section{SIBLING CARE - SIBLINGS CARING FOR ADULTS WITH INTELLECTUAL DISABILITIES}

The increasing life expectancy of adults with intellectual disabilities has raised new questions and challenges for families. Depending on the severity of their condition, people with intellectual disabilities 
need support from their families and environment to vary degrees throughout their lives. They depend on their family members, which addiction is a new problem as parents get older, and care will be the responsibility of siblings who are already living independent lives, sometimes geographically far away. Sibling care should be interpreted differently than when it is performed by a parent or a paid carer, it is more emotionally complex, its content and direction are diverse. We know not too much about sibling caregivers, we only have hypothetical answers to the questions based on a small number of studies or research in similar areas. This paper aims to provide an overview of the situation and motivations of adults who care of and take responsibility for their siblings with intellectual disabilities, and of their role and interaction of the various influences that help them understand. Getting to know siblings is necessary in order for the support system of the special education and social policy to adapt properly to the situation of the - unfortunately - barely 'visible' population.

Keywords: care, intellectual disability, sibling caregivers, sibling caregivings

Discipline: pedagogy

\section{Bevezetés}

A KSH adatai szerint Magyarországon a lakosság 4,3\%-a fogyatékos, de az orvosi szolgáltatások fejlődése és az életminőség javulása miatt a fogyatékos személyek élettartama megnőtt. A várható élettartam az 1930-as években tapasztalt 33 évéről 1993ban 66 évre nőtt és manapság sokan még tovább élnek (US Census Bureau, 2011).

Minden kormánynak - az értelmi fogyatékos állampolgárainak az élettartam növekedése miatt három problémával kell szembenézni annak ellenére, hogy az értelmi fogyatékosok egészségi állapota a többségi társadalomhoz hasonlóan, de azoknál fokozottabban romlik, de a gyógyítás a szintén romló kognitív, mentális állapot miatt tovább nehezedik (Marks és Sisirak, 2010). A gyorsabban romló egészségi állapotuk miatt nagyobb szükség van az intenzív gondozásukra, viszont az értelmi fogyatékos személyek számára nincs megfelelő és elegendő rendelkezésre álló egészségügyi és szociális szolgáltatás.

Az 1960-as évekig a fogyatékos személyek nagy intézményekben éltek még a fejlett országokban is, ahol a nyújtott gondozási tevékenységek mellett az önállóságuk erősen korlátozott volt. Az elmúlt évtizedekben nemzetközi szinten gyors változások történtek a normalizációs elv elfogadása és terjedése miatt, amiben a civil szervezetek is a családok követelései mellé állva nagy szerepet játszottak, megteremtve a támogatási formák széles skáláját (Kim és Dymond, 2012). A hosszabb élettartam miatt is ugrásszerúen megnőtt az igény, aminek kielégítésére jelentős anyagi- és humán erőforrás szükséges. A harmadik problémakört a családokban bekövetkező változások okozzák, leggyakrabban a szülők halála után kialakult helyzet, amikor is a fogyatékos családtagról a testvérek gondoskodnak, magukra vállalva a gondozást (Heller és tsai, 2008). A gondozás kifejezés magában foglalja a napi vagy az időszakos érzelmi, személyes és szociális ellátásnak és támogatásnak biztosítására fordított időt és energiát.

Magától értetődik, hogy a tipikusan fejlődő testvérek támogatást nyújtanak egymásnak felnőttkorban, amelyben a kölcsönösség egyikőjük fogyatékossága miatt hagyományos értelemben nem alakul ki. A nem fogyatékos testvérrel szemben kimondva vagy kimondatlanul, de megfogalmazódik az elvárás, az igény, hogy a támogatásra szoruló testvérérôl gondoskodjon. A nem fogyatékos test- 
vérek különböző fajtájú és mértékű tapasztalatokat szereznek gyermekkorukban, attól függően, hogy a szülők milyen mértékben vonták be őket a testvérükkel kapcsolatos feladatokba, illetve az idősödő szüleik közelében élnek-e, s ha igen, igényelték-e a segítséget. Vannak, akik aktív résztvevői az értelmi fogyatékos családtag ellátásának, de vannak olyanok is, akiknek szinte semmilyen ismerete nincs erről (Heller és tsai, 2008).

Az elképzelések szerint egy fogyatékos személy családon belüli gondozása nem egy állandó egyensúlyban és azonos szinten stagnáló folyamat, hanem folyamatosan változik, amit pl. a gondozás motivációi és akadályai billentenek ki. Mint ahogyan a szülők esetében, a testvérgondozókkal kapcsolatban is az életkoruk (hogy éppen melyik életszakaszukat élik), illetve a kötelezettségeik befolyásolják azt, hogy milyen mértékben vesznek, vagy nem vesznek részt a testvérük gondozásában. Vannak olyan tényezők, amelyek jellegüktől és mértéküktől függően ösztönzik arra, vagy megakadályozzák abban a testvéreket, hogy a gondozásban részt vállaljanak (Lohrer, Lukens és Thorning, 2007). A tényezők között a gondozási szükséglet mellett - a testvérek személyes jellemzőit, - a testvérek kapcsolatát, - a családdal kapcsolatos tényezőket és - a közösségi (külsô) támogatások meglétét vagy hiányát érdemes megvizsgálni.

\section{A testvérek jellemzői}

A különböző vizsgálatok a testvérek életkorára legtöbb esetben rákérdeznek, de a testvérek gondozás iránti hajlandósága, az ezzel kapcsolatos összefüggések nem ismertek. A fiatal felnőttkort nagy változások jellemzik, például a szülőktôl való elköltözés, a lakhatási és gazdasági függetlenség, valamint párkapcsolat kialakítása, a tanulmányok befejezése, szakmai karrier elkezdése. A kutatások, amelyek az értelmi fogyatékosokkal és a mentális betegekkel foglalkoztak, arra mutattak rá, hogy a fogyatékos testvér mellett szerzett tapasztalatok a testvérek érdeklődését tágítják, s befolyásolhatják a pályaválasztásukat, munkavállalásukat. A választott munkakörük miatt gyakran fogyatékosokkal kapcsolatos tanulmányokat folytatnak, és ilyen munkát választanak (Marks, Matson, és Barraza, 2005). Ezzel szemben azok a testvérek, akik kevesebb időt töltöttek a mentális betegségben szenvedő testvérükkel, kevésbé vettek részt az ellátásukban, a kortársakkal töltött időt alig befolyásolta a testvérük léte és a pályaválasztásukra sem volt hatással (Horwitz és tsai, 1992).

A 30-as, a korai 40-es korosztály saját családot alapított, gyerekük született, gyermeket nevelnek, óvodába-iskolába viszik, a családi élet mindennapos gondjaival küzdenek, teljes munkaidőben, esetleg másodállásban is dolgoznak. A felnôtt élet általános gondja és feladatai ellenére (vagy éppen ezért?) megerősödik a korosztályban a ,gyermeki felelősségérzet”, a „szülőkkel kapcsolatos kötelességtudat". Feltételezhetô, hogy nem csak a szülőkkel, de a támogatásra szoruló más családtagokkal, elsősorban az értelmi fogyatékos testvérrel kapcsolatban is kialakul és megerősödik a felelősségérzet, gyakrabban keresik fel a családjukat, vállalnak át feladatokat a szüleiktől.

A középkorúak életében ugyan a szakmai, a családi és a közösségi felelősség némileg átalakul, de új jellemző az egészségi állapotuknak a változása, kisebb-nagyobb betegségek jelentkeznek, ami befolyásolja az életvitelüket, a teherbírásukat és az anyagi helyzetüket is (hiszen már kevésbé tudnak másodállást vállalni, a gyógyszerek, a kezelések pénzbe kerülnek). A fokozatos egészségi állapotromlás befolyásolja a testvérükkel kapcsolatos gondozói szerepüket, ami stresszhez, konfliktusokhoz és rossz közérzethez vezethet, és esetleg kezdenek egyre kevesebbet vállalni a testvérük gondozásából. Ezekben az években a barátok és a környezet sokat segíthet a nem fogyatékos testvéreknek, hogy minél jobban megfelelhessenek még a kötelezettségeiknek.

A hatvanas és idősebb korosztály már maga is egyre jelentősebb fizikai és kognitív változásokat 
tapasztalhatnak magukon, amelyek befolyásolhatják azt, hogy továbbra is megfelelő támogatást és gondozást nyújtsanak a testvérüknek. Egyre kevesebb feladatot tudnak ellátni az értelmi fogyatékos testvérük körül és velük kapcsolatban, esetleg már ők is kisebb-nagyobb segitségre szorulnak.

A testvérek neme jelentős szerepet játszik a gondozói tevékenységek „kiosztásában” és fenntartásában már gyermekkorban is. A lányok azzal az elvárással nőnek fel, hogy nekik kell majd vállalni a jövőbeni gondozási feladatokat (Marks és tsai, 2005). A vizsgálatok ezt az attitűdöt igazolják vissza, mert az adatok szerint a fogyatékos személyek lánytestvére az, aki nagyobb részt vállal gondozásból, támogatásból (pl. Orsmond és Seltzer, 2000), és terveik szerint még többet szeretnének tenni a testvérükért a későbbiekben (Burke és tsai, 2012).

A születési sorrenddel kapcsolatban a vizsgálatok megállapították, hogy az idősebb testvérek azok, akik inkább érintettek (Schuntermann, 2009), talán a korai gyermekkorban a szülők elvárásai miatt. Ha ezt a két megállapítást megfordítjuk, akkor azt is látnunk kell, hogy a fiatalabb testvérek, vagy a fiútestvérek a háttérbe szorulnak vagy húzódnak. Az pedig, ha valaki egyedüli testvére egy fogyatékos személynek, függetlenül attól, hogy fiatalabbról vagy idősebbről van szó, a két testvéres lét erősen összefügg a jövőbeni gondozással kapcsolatos elvárásokkal (Burke és tsai, 2012).

A szakmai karrierépítés a felnőtt élet egyik legfontosabb célja és feladata, ami folyamatos, és amihez a környezet támogatása szükséges. Az értelmi fogyatékos gyermekek anyái nagyobb arányban dolgoznak részmunkaidőben és kevesebbet keresnek, mint általában a gyermekes nők.

Egy értelmi fogyatékos gyermek ellátása megbillenti az egyébként is érzékeny egyensúlyt a család és a munkahely (karrier) között, és konfliktust eredményezhet a munka és a speciális szülói szereppel járó felelősség között. A vizsgálatok azt mutatják, hogy az egyik szülő kénytelen csak részmun- kaidőben munkát vállalni vagy végleg elhagyni a munkaerőpiacot (Parish és tsai, 2004; Stabile és Allin, 2012).

Felmerül a kérdés, hogy testvérek gondozását ellátók munkavállalásával is hasonló történik-e, hogyan és milyen egyensúlyt tudnak kialakítani és megtartani. Kérdés lehet, hogy a gondoskodó testvérek elégedettek-e a családi és a szakmai életükkel, mindezek miatt tudnak-e annyi felelősséget és feladatot vállalni a testvérükkel kapcsolatban, amennyit szeretnének. A felsorolt kérdésekre azonban még nem tudjuk a választ, mert az ismert vizsgálatok még nem fókuszáltak a családi kapcsolatoknak ezen elemeire.

A felnőtt testvérek kapcsolatában a földrajzi távolság még napjainkban, az internet és különböző eszközei ellenére is, meghatározó. A közelebb élő testvérektől várható el és el is várják, hogy intenzívebben legyenek jelen a fogyatékos testvérük ellátásában tevőlegesen és érzelmileg is (Burke és tsai, 2012; Seltzer és tsai, 2005). A szakemberek tapasztalatai (vizsgálataik alapján) kétféle véleményt képviselnek. Az, hogy melyik jellemző egy-egy esetben, magától a családtól, a testvérek személyiségétől, életkörülményeiktól, életük addigi tapasztalataitól függ, azaz előre biztosan nem jósolható meg.

$\mathrm{Az}$ értelmi fogyatékos személlyel együtt vagy ahhoz nagyon közel élő testvér kötődése, felelősségtudata és a ránehezedô nyomás magasabb, amit az, hogy a mindennapos problémákat napi szinten meg kell oldani (Horwitz és tsai, 1992). A testvérük gondozása miatt az életterük, kikapcsolódási lehetőségeik, tevékenységeik beszúkülnek, a munkavállalásban, kapcsolattartásban korlátozottak. A testvérük miatt a családi költségvetés fontos részévé válnak a szociális juttatások, járadékok.

Vannak olyan vélemények is, amelyek szerint éppen a mindennapiság az, ami a gondozás nehézségét és a nyomasztó kötelességtudatot csökkenthetik, míg a távolban élő testvérek számára a gondozás stresszesebb, mert nem tudnak olyan 
mértékben és módon gondoskodni, ahogyan a felelősségtudatuk diktálná (Carpentier és tsai, 1992).

A családgondozás, ezen belül a saját családtag gondozása minden kormánynak fontos szociális kérdés kell, hogy legyen. A kérdés azért is fontos, mert vizsgálatok (Reinhard és Horwitz, 1995) bizonyítják, hogy a gondozást végző személyek (családtagok) nagy része a hozzátartozójuk gondozását a velejáró teher miatt negatívan élik meg. A gondozással járó teher magában foglalja a fizikai és az anyagi szükségletek miatti, a jelen és a jövő iránti negatív érzéseket, szorongásokat, aggodalmakat, amelyek a testvérek életkorával egyre erősödnek.

Az Easter Seals tanulmánya (2012) szerint a megkérdezett testvérek 14\%-a élt a fogyatékos testvérükkel, akik közül 23\%-uk arról számolt be, hogy ő az, aki gondozó. Így például felelős az orvosi és a jogi döntésekért, sőt 75\%-uk a gondozást teljes munkaidőben végzi. Esetükben nyilvánvaló, hogy az intenzív 24 órás gondozói munka miatt a pihenésre, a rekreációra, az egészséget szolgáló szokásokra fordítható idô sérül, ami a fizikai és mentális megterhelést tovább fokozza. Ezt tudva, vagy nem vállalják a gondozást, vagy fokozatosan hátrébb lépnek, miközben a fogyatékos testvér közérzetére, fejlődésére, önállóságára is hatással vannak (negatívan).

Ha megfordítjuk a képet, akkor azt is láthatjuk, hogy amikor a gondozást végző személy pozitív érzéseket és helyzeteket is megél, akkor annak olyan pozitív hozadéka van, mint a fogyatékos személy fejlődése, önállósodása, elégedett közérzete, alkalmazkodó képességének a javulása (Easter Seals, 2012; Raver, Michalek és Gillespie, 2011).

A gondozási tevékenységgel kapcsolatos pozitív érzések csökkenthetik azt, hogy az egyén milyen súlyosnak éli meg a gondozási terhet, illetve megerősítheti az elkötelezettségüket.

A negatív érzések kialakulását, megmaradását, esetleg az erősödését befolyásolják a megküzdési stratégiák, amelyek közül a problémaközpontú stra- tégiák jobb pszichológiai eredményekhez vezetnek, szemben az elkerüléssel vagy az érzelemközpontú megküzdési stratégiával. A problémaközpontúság a helyzetek megoldásában, a mindennapok szervezésében a testvérek közötti kapcsolatot teszi szorosabbá, ami viszont pozitívan visszahat magára a gondozásra (Orsmond és Seltzer, 2007).

Fontos lenne annak megvizsgálása, hogy egyes testvérek hogyan és miért tartják fenn a pozitív gondolkodást és a gondozásban való részvételük intenzitását annak ellenére, hogy kihívásokkal kell szembenézniük. A testvéreknek az a képessége, hogy a pozitívumra összpontosítsanak, inspirációt adhat más testvéreknek, további változókat fedhet fel, és kihatással lehet a politikára és a gyakorlatra.

Számos vizsgálat hívta fel a figyelmet arra, hogy az értelmi fogyatékos (vagy mentális beteg) gyerekeiket nevelő szülók fokozottabban stresszesek, aminek oka a mindennapok szülte kihívásokhoz társuló gondozási nehézségek és terhelés. A vizsgálatok megállapították, hogy a fogyatékos személyek anyái elszigeteltségről, a környezetből érkező neheztelésről, saját keserűségükről, valamint a gondozással és a depresszióval kapcsolatos frusztrációról számoltak be, amelyek az idő múlásával fokozódtak (Baker, Seltzer és Greenberg, 2011; Orsmond és tsai, 2007). A nem csak a családtagokra, hanem a külső gondozókra is kiterjedő vizsgálat rámutatott arra, hogy szignifikánsan magasabb arányban számoltak be ízületi gyulladásról, magas vérnyomásról, elhízásról és az aktivitás korlátozásáról, mint az általános népességben élő kortársaik (Yamaki, Hseih és Heller, 2009). A leírt helyzetben a stressz szintje jelentősen csökken, ha a család kapcsolati, szociális és agyagi támogatása magasabb.

Nem született hasonló témában vizsgálat a testvérekre fókuszálva, de feltételezhető, hogy a negatív fizikai és mentális egészségi állapot befolyásolja az értelmi fogyatékos testvérükkel, azok ellátásával kapcsolatos attitűdöt. Esetükben is feltételezhető, hogy ha kevésbé érzik magukat támogatottnak, az 
hozzájárulhat a magasabb stressz-szinthez, a terhelés fokozott érzékeléséhez, a depressziós tünetek megjelenéséhez és talán ki is lépnek a testvérük gondozásából.

\section{A testvérek kapcsolata}

A testvérek kapcsolatát, a nem fogyatékos testvér részvételét a gondozásban befolyásolja a fogyatékosság típusa és súlyossága (ideértve a viselkedési problémákat és a mentális betegségeket is). A szükségletek érzékelése valójában egy „hinta”alkalmazkodást indíthat el, ami szerencsés esetben egy mindenkinek kielégitő ponton áll meg, legalábbis egy időre. A testvérnek az értelmi fogyatékosságából fakadó magasabb szükségletszintje, a testvér részéről ennek érzékelése ösztönözheti a nem fogyatékos testvért arra, hogy nagyobb részt vállaljon a gondozásban a kapcsolat (addigi) minőségétől függetlenül (Jewell és Stein, 2002; Pruchno, Patrick és Burant, 1996). A gondoskodással járó teher, nehézség és lekötöttség azonban arra késztetheti a testvért, hogy kevesebbet vállaljon, némileg eltávolodjon a gondozott testvérétól (Rimmerman és Raif, 2001).

Hodapp és Urbano (2007) vizsgálata szerint a Down-szindrómás egyének és testvérük/testvéreik kapcsolata szorosabb és melegebb volt, míg Orsmond és Seltzer (2007) azt tapasztalta, hogy kevésbé terveznek szoros kapcsolatot az autizmus spektrum zavarral, viselkedési problémákkal vagy mentális betegséggel küzdő testvérükkel.

Ezen túl-menően az autizmus spektrumzavarral, a hiperak-tivitással együtt járó figyelemzavarral diagnosztizált testvérek fokozottabb kockázatot jelentenek az internalizáló/externálizáló problémák kialakulására, a társadalmi elszigeteltségre (Fisman és tsai, 2000).

Az értelmi fogyatékosok testvéreinek kétharmada az egyik vizsgálat során azt vallotta, hogy vállalja a jövőbeni gondozási feladatokat, míg a mentális betegségben szenvedők (viselkedési problémákkal és nagyobb támogatást igénylők) testvérei közül csak egyharmada tervezte ezt. Ha a jövőbeni gondozási, támogatási hajlandósággal kapcsolatos adatokat egymásra vetítjük, akkor világosan látható, hogy a testvérek terveire vonatkozóan az agresszív viselkedés mértéke a legjelentősebb előrejelző faktor (Unwin és Deb, 2011).

A fenti megállapításoknak két elsődleges értelmezése van. Először is, az autizmus spektrum zavarral küzdő és a mentális betegségekben szenvedők gondozási igényei túlzottá válhatnak a rossz alkalmazkodó képességük miatt, ami pedig elriaszthatja a testvéreket, akik inkább kevesebb részt vállalnak a gondozásból. Másodszor, a súlyosabb állapotú, több támogatást igénylő értelmi fogyatékosok gondozása során a testvérek kénytelenek egyre jobban kérni és bevonni a hivatalos rendszer szolgáltatásait is. A külső segítség belépésével bizonyos tevékenységek alól felszabadul a testvér, ezzel együtt a testvérek együtt eltöltött ideje, intenzitása fokozatosan csökkenni fog (Pruchno és tsai, 1996).

A kérdés megválaszolásához - miért tartják fenn egyes testvérek a kapcsolatot, míg mások nem többen abból indulnak ki, hogy a testvérviszony múltja és jelenlegi jellege meghatározhatja a jelenlegi és jövőbeni érintettséget. Azok a testvérek, akiknek gyermek- és ifjúkorában, majd felnőttként is több pozitív élményú közös tevékenységük volt/van az értelmi fogyatékos testvérükkel, saját felelősségüknek is érzik a feladat átvételét, nem csak eleget akarnak tenni a szüleik elvárásának. (Bigby, 1996; Griffiths és Unger, 1994). Különböző vizsgálatok egyhangúlag azt mutatják, hogy az egyének a testvérkapcsolataikat többnyire pozitívnak minősítették (Burbidge és Minnes, 2014; Hodapp és Urbano, 2007), de hogy ezek közül hány testvér választja a tényleges együttélést, újabb, longitudinális kutatásokat igényelnek. A nyomon követés során viszont fontos szem előtt tartani azt is, hogy a kapcsolatok nem maradnak statikusak, és számos személyes és kontextusbeli tényező befolyásolhatja azokat (Hodapp és Urbano, 2007). 


\section{Családdal kapcsolatos tényezők}

A gondozás, mint a kultúra eleme, társadalmilag meghatározott, közvetlen hatással lehet a gondozó egészségére, meggyőzződésére és tapasztalataira. Az adott tárdadalom vagy társadalmi csoport (szub)kultúrája befolyásolja a családi értékeket, és meghatározzák az olyan elemeket, mint a családtagok felelőssége, normái, a család fontossága, szükségletei és a közösségi támogatások felhasználása (Jones és tsai, 2011).

A különböző nemzetiségek a kultúrájuk szerint markánsan másképpen gondolkodhatnak a segítségre szoruló családtagok támogatásáról. Például az USA-ban éló ázsiai-amerikai családok a súlyosabb egészségügyi problémákkal küzdő idős családtagjuk ellátásához sem kérnek külső segítséget, mert az ázsiai kultúrákban ez azt jelentené kifelé, hogy a család nem képes támogatni a családtagot, és ez elitelendő (Jones és mtsai, 2011). Az ilyen kulturális értékek azonban veszélyeztethetik a gondozást végző testvérek testi és lelki egészségét, nehezítve a gondozást.

Gyermekkorban a testvérek arra törekszenek, hogy segítsék a szüleiket, és átvállaljanak bizonyos szülői feladatokat, enyhítve a családi stresszt és a szülők kötelezettségeit fogyatékos testvéreikkel kapcsolatban. (Schuntermann, 2009). Míg gyerekkorban önként segítenek, ami büszkeséggel tölti el őket, addig felnőttkorban a kialakult helyzet, a szülő egészségi állapotának romlása vagy a haláluk az, ami talán kényszerként hat rájuk (Rimmerman és Raif, 2001; (Orsmond és Seltzer, 2000). Az idősödő szülők remélik és arra számítanak, hogy a gyerekük átveszi a fogyatékos gyermekük gondozását, miután már nem élnek (Heller és tsai, 2008; Jewell és Stein, 2002).

A testvérgondozás szükségessége és nyilvánvaló okai ellenére vannak idôsödő szülők, akik nem biztos, hogy szeretnék a jövőben a gyerekük felnőtt életét a testvérük gondozásával terhelni. $\mathrm{Ha}$ a szülők úgy gondolják, hogy igazságtalan a gyermekükkel szemben a testvérükkel kapcsolatos felelősséget kérni, akkor a kommunikációjukkal távol is tartják őket a gondozással kapcsolatos döntésektôl és tevékenységektől (Smith, Hatfield és Miller, 2000).

A szülőkhöz hasonlóan a testvérek házastársai és gyermekei is fontos szerepet játszanak abban, hogy a testvér mennyire szeretne részt venni az értelmi fogyatékos testvér életében és gondozásában. (Easter Seals, 2012; Taylor és tsai, 2008). Nem lehet vizsgálati adatokat találni azzal kapcsolatban, hogy mi történik a testvér kapcsolataival, ha aktívan feladatot vállalnak (vagy csak akarnak vállalni) a gondozásban a szülők elvárása vagy a házastárs ellenállása ellenére is.

Griffiths és Unger (1994) a családi elvárásokat vizsgálták, aminek alapján azt fogalmazták meg, hogy a testvér gondozásával kapcsolatos implicit elvárása nem elég meghatározó. A szülőknek azt az elképzelését, hogy a gyermekük/gyermekeik a jövőben majd átvállalják a felelôsséget, felülírhatja a gyermeküknek a házassága, a családalapításával együttjáró változások. De a szerzók azt is hangsúlyozzák, hogy a szülők és a testvérek közötti egyértelmú és közvetlen kommunikáció a jövőbeli gondozás alapvető feltétele, a jövőtervezéssel kapcsolatos nyílt családi kommunikáció pozitívan formálja a testvérek felelősségvállalását és a gondozási terveit. A halogatott vagy a problémáról nem az életkori sajátosságoknak megfelelő szinten való beszélgetések akadályozzák, hogy a testvérek saját maguk formálják a jövőképükben a saját szerepüket (Easter Seals, 2012). A folyamatos és megfelelő szintű kommunikáció és tervezés hiánya szorongást okozhat, amikor a testvérek (esetleg) váratlanul olyan helyzetbe kerülnek, hogy dönteniük kell a testvérük gondozásáról (Griffiths és Unger, 1994). Anderson, Larson és Wuorio (2011) adatai szerint az értelmi fogyatékos családtag teljes állásban való gondozása az esetek 81\%-ának (n = 4962) pénzügyi megterhelést jelentett, aminek a mértéke függ a fogyatékosság súlyosságától (Lohrer és tsai, 2007). A testvérüket gondozók $60 \%$-a $(\mathrm{n}=351)$ számolt 
be arról, hogy aggódik a hosszú távú pénzügyi helyzetük miatt, 40\%-a pedig arról, hogy már a vizsgálat idôpontjában is voltak anyagi gondjai, vagy nem volt megtakarítása, nem tudott volna egy váratlan kiadást fizetni, ami állandó stresszt okozott (Easter Seals, 2012). Még nem ismertek azok az összefüggések, amelyek a gazdasági helyzet és kilátások, valamint a gondozás és mértékének vállalása között vannak.

A testvérrôl való gondoskodás az aktuális agyagi helyzet mellett függ attól is, hogy a testvérek származási családja milyen társadalmi-gazdasági helyzetű volt. Parish és munkatársai (2004) arról számoltak be, hogy az fogyatékos személyt neveló családoknak a megtakarításai közel 27\%-kal alacsonyabbak, mint az átlag családoké. A kisebb tartalék oka lehet, hogy az anyák nagy valószínúséggel nem dolgoznak vagy csak részmunkaidőben, így kevesebbet keresnek, mint a tipikusan fejlődó gyermekeket nevelő családokban (Stabile és Allin, 2012). Ha a szülók gyermekkorban nem tudnak megfelelő anyagi biztonságot nyújtani, majd nem tudják segíteni a gyermekük önálló életkezdését, akkor a saját élményeik miatt kevésbé fognak elköteleződni a fogyatékos testvérük gondozása mellett.

Az eddig még feltáratlan összefüggések talán legfontosabb kérdése, hogy vajon a fogyatékosságoknak minden típusa és szintje pénzügyi terheket és munkavállalási nehézségeket eredményez-e, és a pénzbeli állami támogatások mérséklik-e a család nehéz pénzügyi helyzetét.

\section{Közösségi források és támogatás}

Elfogadható az a vélemény, hogy a legtöbb felnőtt testvér hajlandó lenne az értelmi fogyatékos testvérük gondozójává lenni, de gyakran felkészületlennek érzik magukat és aggódnak a felelősség miatt. A gondozással kapcsolatos ügyintézés ismeretlensége, a pénzügyek miatti aggodalmak, a gondozói státusszal járó döntések, valamint a gondnoksággal kapcsolatos információk hiánya az, ami miatt a testvérek elbizonytalanodhatnak, ag- gódhatnak, hogy meg tudnak-e birkózni a sokrétú feladattal (Heller és tsai, 2008). Az Easter Seals tanulmánya (2012) szerint a mindennapokban a testvéreknek segítségre van szükségük a szállításban, az orvosi ellátás megszervezésében, a pénzügyek kezelésében, a napi ellátásban, valamint a testvérük megfelelő foglalkoztatásának, közösségi életének a megszerzésében és fenntartásában. A felnôtt fogyatékos testvérek és az őket gondozó testvérük által igénybe vehetô állami, civil szférás és közösségi támogatási programok hatásáról nincsenek meggyőző tanulmányok, ennek ellenére a kutatása kétségtelenül fontos.

A szakértők egyetértenek abban, hogy a támogató „testvércsoportok” lehetôvé teszik a családtagok számára, hogy betekintést nyerjenek a testvérüket is érintő állapotokba, és hatékonyan megbirkózzanak a gondozás nehézségeivel (Lukens, Thorning és Lohrer, 2002). A testvérek felkészületlennek érzik magukat a gondozásra, ezért a támogató csoportok segíthetik őket a hatékony gondozói készségek fejlődésében, abban, hogy válsághelyzetben a lehető legjobb módon reagáljanak, és azzal, hogy a testvéreket támogató programok (csoportok) a legkorszerúbb információkat nyújtsák egymásnak. A csoportok enyhíthetik az állapotát azoknak a gondozó testvéreknek, akiknél a mentális egészségi problémák szignifikánsan gyakoribbak.

Magyarországon nem csak nincs egységes testvértámogató rendszer vagy alternatíva, de kialakulásának a legelején tartunk, amire pedig több okból is nagy szükség lenne. A testvérek nemcsak a gondozást végzik, hanem meg is könnyíthetik a hivatalos szolgáltatók közötti kommunikációt, és alternatívát jelenthetnek az értelmi fogyatékos személy intézményi elhelyezésével szemben (Sibling Leadership Network, 2013).

\section{Összegzés}

Annak ellenére, hogy a testvérgondozás kulcsfontosságú kérdés sok család számára, még mindig 
nagyrészt felderítetlen a terület, sok a megválaszolatlan kérdés, a csak feltételezett, de nem igazolt összefüggés. Mivel minden megválaszolatlan kérdés kihatással lehet a gyakorlatra, a szociál- és a családpolitikára, szükség lenne több kutatásra, aminek néhány fontos kérdése már most is megfogalmazható. Melyek a testvérek motivációi a gondozói szerep, a kihívások vállalására? (Heller és tsai, 2008); Hogyan történik, milyen szempontok és jellemzők mentén a gondozás felelősségének a felosztása, ha több testvér van a családban? Hogyan látják a testvérgondozók saját életüket, céljaikat, milyen a jövőképük (saját család alapítása, szakmai és privát életük)? Milyen támogatásra van szükségük a gondozó testvéreknek a különböző életszakaszokban és élethelyzetekben?

A kérdésekre olyan longitudinális vizsgálatok válaszolhatnak, amelyek az időfaktort szem előtt tartva szélesítik és mélyítik el a témát (Burke és tsai, 2012; Dew, Llewellyn és Balandin, 2004). A testvérgondozók motivációinak és a helyzetüknek több tényező, pl. a faji és etnikai hovatartozás, a társadalmi, a gazda-sági helyzet, a gondozás pénzügyi, fizikai és mentális egészség, valamint ezek összefüggései befolyásolják, amelyeket ismernünk kellene, hogy kidolgozhatók legyenek a megküzdési stratégiák, valamint az, hogy a saját státuszukat hogyan értékelik. A gondozás különböző kihívásainak ezen változók alapján történő megértése kihatással lehet a támogató programokra és szolgáltatásokra.

\section{Irodalom}

Mikrocenzus 2016. A fogyatékos és az egészségi ok miatt korlátozott népesség jellemzői. Központi Statisztikai Hivatal, 2018, Budapest

U.S. Census Bureau. (2011). American Community Survey. Retrieved from Net: http://factfinder2. census.gov/faces/tableservices/jsf/pages/prod uctview.xhtml?pid=ACS_11_1YR_S1810éspro dType=table Letöltés: 2020. 09. 21.
Baker, J. K., Seltzer, M. M., és Greenberg, J. S. (2011). Longitudinal effects of adaptability on behavior problems and maternal depression in families of adolescents with autism. Journal of Family Psychology, 25, 601-609. doi: $\underline{10.1037 / \mathrm{a} 0024409}$

Bigby, C. (1996). Transferring responsibility: The nature and effectiveness of parental planning for the future of adults with intellectual disability who remain at home until mid-life. Journal of Intellectual and Developmental Disabilities, 21, 295-312. doi: $10.1080 / 13668259600033211$

Burbidge, J., és Minnes, P. (2014). Relationship quality in adult siblings with and without developmental disabilities. Family Relations, 63, 148-162.doi: $\underline{10.1111 / \text { fare.12047 }}$

Burke, M. M., Taylor, J. L., Urbano, R., és Hodapp, R. M. (2012). Predictors of future caregiving by adult siblings of individuals with intellectual and developmental disabilities. American Journal of Intellectual and Developmental Disabilities, 117, 3347.doi: 10.1352/1944-7558-117.1.33

Carpentier, N., Lesage, A., Lalonde, P., Goulet, J., és Renaud, M. (1992). Burden of care of families not living with young schizophrenic relatives. Psychiatric Services, 43, 38-43. doi: 10.1176/ps.43.1.38

Dew, A., Llewellyn, G., és Balandin, S. (2004). Post-parental care: A new generation of siblingcarers. Journal of Intellectual and Developmental Disability, 29, 176-179. doi: $\underline{10.1080 / 13668250410001709520}$

Easter Seals (2012). Easter seals siblings study. Retrieved from http:// www.easterseals.com Lexplore-resources/siblings-study.html Letöltés: 2020. 09. 21.

Fisman, S., Wolf, L., Ellison, D., és Freeman, T. (2000). A longitudinal study of siblings of children with chronic disabilities. Canadian Journal of Psychiatry, 45, 369-375. doi: $\underline{10.1177 / 070674370004500406}$ 
Griffiths, D. L., és Unger, D. G. (1994). Views about planning for the future among parents and siblings of adults with mental retardation. Family Relations, 43, 221-227.

Heller, T., Kaiser, A., Meyer, D., Fish, T., Kramer, J., és Dufresne, D. (2008). The sibling leadership network: recommendations for research, advocacy, and supports relating to siblings of people with developmental disabilities. Paper presented at the Sibling Leadership Network Meeting. Retrieved from http://www.siblingsupport.org/sln-whitepaper-final-2.pdf Letöltés: 2020. 09. 21.

Hodapp, R. M., és Urbano, R. C. (2007). Adult siblings of individuals with Down syndrome versus with autism: Findings from a large-scale US survey. Journal of Intellectual Disability Research, 51, 1018- 1029. doi: 10.1111/j.13652788.2007.00994.x

Horwitz, A. V., és Reinhard, S. C. (1995). Ethnic differences in caregiving duties and burdens among parents and siblings of persons with severe mental illnesses. Journal of Health and Social Bebavior, 36, 138-150.

Horwitz, A. V., Tessler, R. C., Fisher, G. A., és Gamache, G. M. (1992). The role of adult siblings in providing social support to the severely mentally ill. Journal of Marriage and Family, 54, 233-241.doi: $\underline{10.2307 / 353290}$

Jewell, T. C., és Stein, C. H. (2002). Parental influence on sibling caregiving for people with severe mental illness. Community Mental Health Journal, 38, 17-33. doi: 10.1023/a:1013903813940

Jones, P. S., Winslow, B. W., Lee, J. W., Burns, M., és Zhang, X. (2011). Development of a carer empowerment model to promote positive outcomes. Journal of Family Nursing, 17, 11-28. doi: $10.1177 / 1074840710394854$

Kim, R. K., és Dymond, S. K. (2012). A national study of community living: Impact of type of residence and hours of in-home support.
Research and Practice for Persons with Severe Disabilities: The Journal of TASH, 37, 116-129. doi: $10.1177 / 154079691203700207$

Lohrer, S. P., Lukens, E. P., és Thorning, H. (2007). Economic expenditures associated with instrumental caregiving roles of adult siblings, Community Mental Health Journal, 43, 129-151. doi: $\underline{10.1007 / \mathrm{s} 10597-005-9026-3}$

Lukens, E. P., Thorning, H., és Lohrer, S. P. (2002). How siblings of those with severe mental illness perceive services and support. Journal of Psychiatric Practice, 8, 354-364. doi: 10.1097/00131746-200211000-00005

Marks, B., és Sisirak, J. (2010). Age-related changes for adults with developmental disabilities. Impact Newsletter, 23, 24-25.

Marks, S. U., Matson, A., és Barraza, L. (2005). The impact of siblings with disabilities on their brothers and sisters pursuing a career in special education. Research and Practice for Persons with Severe Disabilities: The Journal of TASH, 30, 205-218. doi: $10.2511 /$ rpsd.30.4.205

Orsmond, G. I., és Seltzer, M. (2000). Brothers and sisters of adults with mental retardation: Gendered nature of the sibling relationship. American Journal on Mental Retardation: AJMR, 105, 486-507. doi: 10.1352/08958017(2000)105<0486:BASOAW>2.0.CO;2

Orsmond, G. I., és Seltzer, M. M. (2007). Siblings of individuals with autism or Down syndrome: Effects on adult lives. Journal of Intellectual Disability Research, 51, 682-696.

Parish, S. L., Seltzer, M. M., Greenberg, J. S., és Floyd, F. (2004). Economic implications of caregiving at midlife: Comparing parents with and without children who have developmental disabilities. Mental Retardation, 42, 413-426. doi: $10.1352 / 0047-$ 6765(2004)42<413:EIOCAM>2.0.CO;2

Pruchno, R. A., Patrick, J. H., és Burant, C. J. (1996). Aging women and their children with chronic disabilities: Perceptions of sibling 
involvement and effects on well-being. Family Relations, 45, 318- 326. doi: 10.2307/585504

Raver, S. A., Michalek, A. M., és Gillespie, A. M. (2011). Stressors and life goals of carers of individuals with disabilities. Journal of Social Work in Disability and Rehabilitation, 10, 115-128. doi: 10.1080/1536710X.2011.571536

Reinhard, S. C., és Horwitz, A. V. (1995). Caregiver burden: Differentiating the content and consequences of family caregiving. Journal of Marriage and Family, 57, 741-750. doi: $\underline{10.2307 / 353928}$

Rimmerman, A., és Raif, R. (2001). Involvement with and role perception toward an adult sibling with and without mental retardation. Journal of Rebabilitation, 67, 10-15.

Schuntermann, P. (2009). Growing up with a developmentally challenged brother or sister: A model for engaging siblings based on mentalizing. Harvard Review of Psychiaty, 17, $297-$ 314. doi: $10.3109 / 10673220903299161$

Seltzer, M. M., Greenberg, J. S., Orsmond, G. I., és Lounds, J. (2005). Life course studies of siblings of individuals with developmental disabilities.

Mental Retardation, 43, 354-359. doi: $10.1352 / 0047-$ 6765(2005)43[354:LCSOSO]2.0.CO;2

Sibling Leadership Network. (2013). Research related to siblings of individuals with disabilities. Retrieved from.
Smith, G. C., Hatfield, A. B., és Miller, D. C. (2000). Planning by older mothers for the future care of offspring with serious mental illness. Psychiatric Services, 51, 1162-1166. doi: 10.1176/appi.ps.51.9.1162

Stabile, M., és Allin, S. (2012). The economic costs of childhood disability. The Future of Children, 22, 65-96. doi: $10.1353 /$ foc. 2012.0008

Taylor, J. L., Greenberg, J. S., Seltzer, M. M., és Floyd, F. J. (2008). Siblings of adults with mild intellectual deficits or mental illness: Differential life course outcomes. Journal of Family Psychology, 22, 905-914. doi: $\underline{10.1037 / a 0012603}$

Unwin, G., és Deb, S. (2011). Family carer uplift and burden: Associations with aggressive behavior in adults with intellectual disability. Journal of Mental Health Research in Intellectual Disabilities, 4, 186- $205 . \quad$ doi: $\underline{10.1080 / 19315864.2011 .600511}$

U.S. Bureau of Labor Statistics. (2009). Labor Force Statistics from the Current Population Survey. Retrieved from http://data.bls.gov/ timeseries/LNS14000000 Letöltés: 2020. 09. 21. Yamaki, K., Hseih, K., és Heller, T. (2009). Health profile of aging family carers supporting adults with intellectual and developmental disabilities at home. Intellectual and Developmental Disabilities, 47, 425-435.doi: $\underline{\text { 10.1352/1934-9556-47.6.425 }}$ 